\title{
Offshore diplomacy, or how seabirds mitigate intra-specific competition: a case study based on GPS tracking of Cape gannets from neighbouring colonies
}

\author{
David Grémillet ${ }^{1, *}$, Giacomo Dell'Omo ${ }^{2}$, Peter G. Ryan ${ }^{3}$, Gerrit Peters ${ }^{1,5}$, \\ Yan Ropert-Coudert ${ }^{6}$, Scarla J. Weeks ${ }^{4}$ \\ ${ }^{1}$ Centre d'Ecologie et de Physiologie Energétiques - Centre National de la Recherche Scientifique, 23 rue Becquerel, \\ 67087 Strasbourg Cedex 02, France \\ ${ }^{2}$ Institute of Anatomy, University of Zürich, Irchel, Winterthurerstrasse 190, 8057 Zürich, Switzerland \\ ${ }^{3}$ Percy FitzPatrick Institute of African Ornithology, and ${ }^{4}$ OceanSpace, University of Cape Town, Rondebosch 7701, South Africa \\ ${ }^{5}$ Earth and Ocean Technologies, Hasseer Strasse 75, 24113 Kiel, Germany \\ ${ }^{6}$ National Institute of Polar Research 1-9-10 Kaga, Itabashi-ku, Tokyo 173-8515, Japan
}

\begin{abstract}
How do seabirds deal with intra-specific competition for food? We addressed this question in a study of the foraging behaviour of 91 Cape gannets Morus capensis from 2 South African colonies, situated $110 \mathrm{~km}$ apart, using GPS and time-depth recorders. Theoretically birds should have widely overlapping foraging areas and comparable foraging characteristics. Surprisingly, the foraging areas only overlapped by 13 and $14 \%$, and birds from the 2 colonies also showed marked differences in their foraging patterns. Birds from the larger colony foraged more intensively; their foraging trips lasted longer (22.6 vs $8.5 \mathrm{~h}$ ), involving longer total flight time ( $7.8 \mathrm{vs} 5.9 \mathrm{~h})$, longer foraging path length (293 vs $228 \mathrm{~km})$, and greater maximum distance from the breeding site (104 vs $67 \mathrm{~km}$ ). They also travelled faster ( $50 \mathrm{vs} 44 \mathrm{~km} \mathrm{~h}^{-1}$ ), and had a larger number of foraging locations during each trip (252 vs 121), with more sinuous foraging paths (1.4 vs 1.1). However, there were no significant differences in the number of dives per foraging trip (68 vs 66), the average maximum depth attained ( 3.4 vs $3.6 \mathrm{~m}$ ), nor the average or total dive duration per foraging trip (4.3 vs $4.3 \mathrm{~s}$ and 5.7 vs $4.3 \mathrm{~min}$, respectively). We conclude that gannets from these 2 colonies are spatially segregated and experience different foraging conditions. We speculate that wind patterns and group feeding could generate such foraging asymmetries. Foraging site fidelity and memory effects could consolidate these asymmetries, and generate 'cultural' differences in foraging patterns.
\end{abstract}

KEY WORDS: Morus capensis · Wildlife telemetry $\cdot$ Geolocation $\cdot$ Home range $\cdot$ Habitat partitioning Optimal foraging $\cdot$ Self-organisation

\section{INTRODUCTION}

Birds often form breeding aggregations (Darling 1938). Such breeding colonies have numerous advantages, for example as a defence against predation, and for the social stimulation of young, inexperienced individuals. Colonies play an important role within selection processes (reviews in Danchin \& Wagner 1997, Coulson 2002). One of the disadvantages of colo- niality is that food resources are generally not present ad libitum within easy commuting distance of the breeding area (Brown et al. 1992). Birds therefore have to travel between breeding and feeding sites. They are termed central-place foragers because they exploit resources within a given range of a central place (i.e. their nest) set by food distribution and the travelling capabilities of the species concerned (Orians \& Pearson 1979, Schoener 1979). Coloniality and central- 
place foraging are most widespread among seabirds, where $96 \%$ of species are colonial (Rolland et al. 1998, Coulson 2002). Most seabirds are truly marine creatures that may wander over entire ocean basins, but all seek solid substrata to reproduce (Schreiber \& Burger 2002). Finding breeding space is a real problem for seabirds because they are vulnerable on land, and particularly attractive to terrestrial predators. They therefore tend to breed on remote islands (King 1983), but these are per se of limited size (Coulson 2002). Due to this space limitation, and to social attraction, many seabirds gather in enormous breeding colonies, with some of these aggregations composed of over a million pairs (Warham 1996). Predatory pressure exerted by birds, and intra-specific competition for food resources, are severe around such massive colonies. This is thought to have 4 main, inter-related effects: (1) Prey depletion is likely to occur around the breeding site (Ashmole 1963). (2) Larger colonies utilize a wider total foraging area, termed the 'Hinterland' (sensu Cairns 1989). (3) Individuals from larger colonies conduct longer foraging trips farther from the nest, and these colonies grow more slowly in size (Lewis et al. 2001, Davoken \& Montevecchi 2003). (4) Large seabird colonies impede the development of smaller, neighbouring breeding sites (Furness \& Birkhead 1984).

To minimise intra-specific competition, seabird colonies should be spaced so that their foraging zones do not overlap (Cairns 1989). Field studies confirm that this is sometimes the case (Wanless \& Harris 1993, Huin 2002). However, islands (and therefore potential breeding sites) are not evenly distributed; for geological reasons they often occur in clusters (Forbes et al. 2000).

What happens when large numbers of a seabird species breed at neighbouring breeding sites (i.e. inter-colony distance is much smaller than the maximum foraging range)?

If food resources are evenly distributed, these colonies might function as subcolonies of a single breeding site (Ainley et al. 1995). This would imply: (1) widely overlapping foraging zones; and (2) similar foraging effort for birds attending these different, yet neighbouring, colonies.

We tested these hypotheses for Cape gannets Morus capensis breeding off the Atlantic coast of South Africa.

Cape gannets are fairly large (average body mass $2.6 \mathrm{~kg}$, Rand 1960) seabirds which feed by plungediving (Ropert-Coudert et al. 2004a) on shoals of pelagic fish such as anchovy Engraulis capensis or sardines Sardinops sagax (Berruti \& Colclough 1987). As a breeding species, they are endemic to islands off the coast of Namibia and South Africa, and are closely linked to the highly productive Benguela upwelling ecosystem in the SE Atlantic. Despite an estimated population of 167000 breeding pairs in 2000 (R. J. M. Crawford et al. unpubl. data), the species only breeds at 6 sites, all situated on inshore islands. These breeding colonies vary widely in size (from 150 to 70000 pairs, R. J. M. Crawford et al. unpubl. data) and distribution (inter-colony distance ranges between 60 and $600 \mathrm{~km}$ ).

Using bird-borne GPS loggers and time-depth recorders, we compared the foraging characteristics of Cape gannets breeding on Bird Island (Lambert's Bay, 17000 breeding pairs, ca. $10 \%$ of the world population), and Malgas (Saldanha Bay, 70000 breeding pairs, ca. $42 \%$ of the world population), 2 sites ca. $110 \mathrm{~km}$ apart. These sites are at least $500 \mathrm{~km}$ away from the 4 other breeding sites. Breeding Cape gannets are thought to forage within $350 \mathrm{~km}$ of the colonies (Percy FitzPatrick Institute unpubl. data). Recent satellite tracking studies show that closely related northern gannets Morus bassanus also forage as far as $540 \mathrm{~km}$ from their colonies when breeding (Hamer et al. 2000). Using a theoretical foraging range of $350 \mathrm{~km}$, the approximate foraging areas of birds from Bird Island and Malgas are 121000 and $175600 \mathrm{~km}^{2}$, respectively, with $89 \%$ of Bird Island's theoretical foraging area overlapping that of Malgas, and $63 \%$ of Malgas' theoretical foraging area overlapping that of Bird Island. This situation thus provides a good natural test of how marine birds deal with intra-specific competition for food. We also took advantage of the recent development of miniaturised GPS and dive-depth data loggers, which allowed us to record the foraging activities of this seabird species with unprecedented accuracy.

\section{MATERIALS AND METHODS}

We studied the foraging behaviour of adult Cape gannets breeding on Bird Island (Lambert's Bay, $32^{\circ} 5^{\prime} \mathrm{S}, 18^{\circ} 18^{\prime} \mathrm{E}$ ) and Malgas (Saldanha Bay, 333' $\mathrm{S}$, $\left.17^{\circ} 55^{\prime} \mathrm{E}\right)$ in the Western Cape, South Africa. All experiments were conducted under the appropriate permits of Cape Nature Conservation (Lambert's Bay) and South African National Parks (Malgas Island). All practical work was conducted on Bird Island between 1 and 10 December 2002, and on Malgas between 10 and 14 December 2002.

Attachment procedure and device effects. Cape gannets raising young chicks were caught at the nest site prior to a foraging trip, and fitted with an electronic tag. Birds were selected at random, i.e. they were not only breeding at the edge of the colony, but also well within it. The tags were attached to the central tail feathers of the birds, with GPS recorders placed on the top of the tail and time-depth recorders placed under 
the tail. Both devices were secured with waterproof tape and fast epoxy during the 6 initial deployments, and then exclusively with tape, as we found that this was sufficient to attain a $100 \%$ recovery rate of the devices. The waterproof tape employed (Wilson et al. 1997) is particularly attractive because it does not damage the plumage of the bird, and can be entirely removed with the device upon recapture. This attachment technique requires ca. $5 \mathrm{~min}$ from capture to release on average, and less than $10 \mathrm{~min}$ in all cases. Every effort was taken to minimize the stress caused to the birds during handling. Air temperatures and light levels were high during the study period, and gannets are prone to overheating (Hochscheid et al. 2002). To minimize this stress factor we equipped birds at day break (when most birds initiated foraging trips), or worked in the shade whenever possible.

The equipped birds stayed at sea for foraging trips of up to $2 \mathrm{~d}$. Upon their return to the nest site they were recaptured, device and tape were removed, and the information stored by the electronic tag was downloaded onto a portable computer.

When on land, none of the equipped birds showed behavioural signs of handicap or even discomfort. They did not 'preen' the package intensively, as seabirds do when disturbed by a device (Wilson et al. 1990). It is nonetheless difficult to know the impact of tagging on individual birds when they are out at sea (Jackson \& Wilson 2002). To assess this potential bias we marked a set of 10 unequipped, undisturbed birds breeding on Bird Island with a small spot of sheep marker. This biocompatible marker does not damage the plumage, and fades completely within a maximum of $2 \mathrm{wk}$. The nest sites of these control birds were checked every $2 \mathrm{~h}$ during daylight hours to record foraging trip length (gannets do not land onto or depart from the colony at night). Foraging trip length is a reliable proxy for foraging effort in gannets (Hamer et al. 2000). We assumed that if equipped birds were impacted by the data loggers, this would affect foraging trip length (see Taylor et al. 2001).

Electronic equipment. Birds were equipped with a GPS recorder, or with a GPS recorder and a time-depth recorder. Each bird was studied for a single foraging trip to reduce pseudoreplication Our data set on GPS tracks nonetheless bares a certain level of pseudoreplication due to the imbalance between the large number of positional fixes recorded for each bird (Wood et al. 2000). We tempered this effect by using a Kernel analysis, and by filtering the data adequately (see 'Spatial analysis').

Three types of devices were used:

(1) A GPS receiver $(62 \times 32 \times 14 \mathrm{~mm})$ with integrated antenna and a $1 \mathrm{Mb}$ flash memory operated by a rechargeable battery (Newbehavior; see Steiner et al.
2000 for a full technical description). Data related to position (latitude, longitude, altitude), speed and time were computed and recorded at $10 \mathrm{~s}$ intervals. In this operating mode, $95 \%$ of the fixes recorded over a $24 \mathrm{~h}$ period were in a radius of $11.6 \mathrm{~m}$. The loggers were sealed into small polyethylene bags (thickness $0.4 \mathrm{~mm}$ ). The overall weight of the device and its waterproof package was $37 \mathrm{~g}$.

(2) The time-depth recorders (TDR) used were miniaturised, cylindrical devices (M190-D2GT, 12 bit resolution, $60 \times 15 \mathrm{~mm}, 20 \mathrm{~g}$; Little Leonardo), deployed in conjunction with some of the above GPS loggers. The devices monitored depth every second with an absolute accuracy of $0.1 \mathrm{~m}$ (see Yoda et al. 2001 and Ropert-Coudert et al. 2004b for details). The mass of the package GPS + TDR was 57 g, i.e. $2.2 \%$ body mass of the bird.

(3) A second type of GPS recorder also was used: the GPSlog (Earth\&Ocean Technologies). This unit also collected time, position, and speed data. The logger was housed in a pressure-tight fibre-composite casing for protection against water and mechanical impact, providing maximum pressure resistance of ca. 3 bar ( $\sim 30 \mathrm{~m}$ water column). An O-ring sealed cap allows easy access to the logger for data retrieval and battery exchange. The mass of the recorder, including battery and watertight housing, was $65 \mathrm{~g}$ ( $2.5 \%$ body mass of the bird). Outer maximum dimensions of the streamlined housing were $95 \times 48 \times 24 \mathrm{~mm}(\mathrm{~L} \times \mathrm{W} \times \mathrm{H})$. Trials showed that the horizontal accuracy of this system was better than $5 \mathrm{~m}$ for $90 \%$ of all fixes in continuous mode. In intermittent mode, the accuracy decreased slightly, but was still within $10(65 \%)$ to $20 \mathrm{~m}(90 \%$ of all fixes). These GPS loggers were set to record every $1 \mathrm{~s}$. Recorded data sets were sub-sampled at $10 \mathrm{~s}$ intervals to allow for joint analysis of data recorded using both types of GPS loggers.

Data handling and analysis. Foraging tracks: The recorded tracks were analysed to compile key information regarding the foraging effort of the birds. Foraging trip duration was determined as the time lapse between departure and return from the colony. We determined the geographic boundaries of the colony and used these to discriminate positions in/out of the breeding site. Foraging path length was calculated as the total cumulative distance between all positional fixes along the foraging track, outside of the colony.

Maximum distance from the breeding colony was calculated using the coordinates of the nest site as a reference. This technique provides underestimates of the true distance when birds fly around land masses (as around the Cape of Good Hope towards the East, for example). In our field situation this was a very isolated phenomenon which was assumed to have negligible impact on the overall results. Time spent flying 


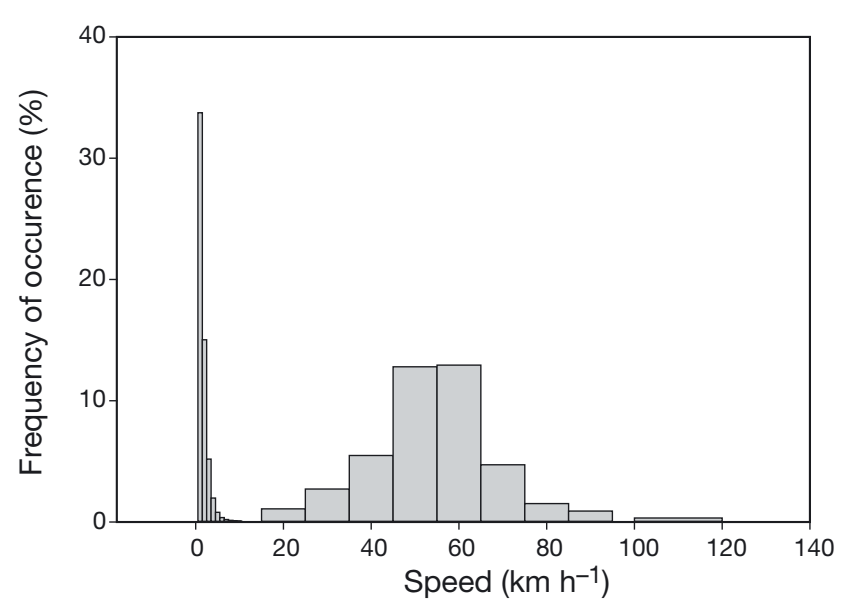

Fig. 1. Morus capensis. Frequency distribution (\%) of speed classes recorded for Cape gannets foraging off Lambert's Bay and Malgas using GPS loggers. The bimodal distribution is attributed to birds resting at the water surface (left peak $<10 \mathrm{~km} \mathrm{~h}^{-1}$ ), or flying (right peak $>10 \mathrm{~km} \mathrm{~h}^{-1}$ )

was defined as the total time outside of the colony for which the GPS speed was $>10 \mathrm{~km} \mathrm{~h}^{-1}$. To determine this threshold value, we examined a frequency distribution of the recorded speeds (Fig. 1), and noticed a clear bimodal, non-overlapping pattern. One mode consisted of speeds $<10 \mathrm{~km} \mathrm{~h}^{-1}$, and corresponded to birds resting on land or at the surface of the sea. The second mode $>10 \mathrm{~km} \mathrm{~h}^{-1}$ corresponded to flying birds.

Path sinuosity was defined as the ratio of the actual flight speed given by the GPS receiver to the velocity between every third fix (i.e. total displacement every $30 \mathrm{~s}$ ). A bird circling around in a more confined area will show a lower calculated speed than the actual GPS speed, and therefore provide a higher sinuosity index.

Spatial analysis: We used criteria of speed and path sinuosity to discriminate sections of the foraging trip during which birds were actively searching for prey. Our rationale was that a gannet actively exploiting a prey patch would spend more time in a certain area than when commuting between feeding patches (see descriptions of gannet foraging behaviour in Nelson 1978). In order to obtain an objective criterion, we developed an algorithm that automatically identified and filtered location fixes associated with prey patch exploitation. In a first step, we excluded all GPS speeds lower than $10 \mathrm{~km} \mathrm{~h}^{-1}$, as these were not associated with flying activity (see above). In a second step, path sinuosity was calculated as specified above, and the remaining data filtered using a threshold sinuosity value. The use of a threshold value is necessary because a certain difference between actual and calculated speed is to be expected in all cases, even during highly directional flight. This is due to small-scale aberrations from the flight path and to vertical movements, which are included in the GPS-speed informa- tion but not in the calculated horizontal speed. This threshold value was determined by visual assessment of GPS tracks, and by comparing these tracks with concomitant recordings of the diving activity whenever possible. This enabled us to segregate location fixes linked to prey patch utilisation via plunge-diving. The best results were obtained by considering all points with a sinuosity $>3.3$. Visual control of the tracks confirmed this procedure to reliably exclude most travelling periods, particularly those where birds were soaring against head or cross winds, and thus flew less directionally, even during commuting.

Using such appropriately filtered GPS data we compiled distribution maps of the recorded position fixes. These were plotted for 2 different sets of fixes. One contained all fixes for birds outside of the colony, the second only contained fixes identified as foraging fixes according to the filter described above.

Density maps were obtained by smoothing the position data on a $0.01^{\circ}$ grid using a Kernel analysis (search radius $=5 \mathrm{~km}$ ). This method is used to reveal areas within which animals foraged preferentially and to temper the effects of pseudoreplication (see Wood et al. 2000). The plots were then mapped as topographic representations using a cylindrical equidistant projection, with $\mathrm{Z}$ giving the density of position fixes per unit area on a $0.01^{\circ}$ grid (this corresponds approximately to a $1.11 \times 0.94 \mathrm{~km}$ grid at this latitude, approximately the same as for the satellite images used in Figs. 6 \& 7).

We calculated the surface areas of 4 different zones for each location:

(1) Theoretical foraging areas for a $350 \mathrm{~km}$ foraging range. Prior to our study, this distance was assumed to be the maximum foraging range for breeding Cape gannets (Percy FitzPatrick Institute unpubl. data). We therefore used a radius of $350 \mathrm{~km}$ and the coastline to calculate these theoretical foraging areas (see Fig. 6).

(2) Foraging areas based on the foraging ranges recorded in our study, and on the $500 \mathrm{~m}$ isobath, which we showed to contain nearly all foraging locations (see 'Results').

(3) Foraging areas as defined using all GPS locations recorded for Cape gannets outside of the colony.

(4) Foraging areas as defined using all filtered GPS locations attributed to active foraging (see above).

We calculated the overlap between the foraging areas of both colonies for each of these 4 zones.

Diving activity: We analysed all recorded data using IGOR Pro (Wavemetrics, Version 4.01). For each foraging trip we determined the total number of dives performed. A dive was defined as a recorded depth of $>0.1 \mathrm{~m}$ lasting for $>1 \mathrm{~s}$. We also determined the maximum depth of each dive, as well as the average and total dive duration over the entire foraging trip (see Ropert-Coudert et al. 2004b). 
Abiotic parameters. Patterns of sea surface temperature (SST), chl a (a proxy for phytoplankton concentration), and wind were assessed using satellite imagery. High resolution $(1 \mathrm{~km})$ NOAA AVHRR (Advanced Very High Resolution Radiometer) and OrbView-2 SeaWiFS (Sea-viewing Wide Field-of-view Sensor) data were acquired and processed locally. Daily images of AVHRR SST were generated using the Multichannel Sea Surface Temperature algorithm (McClain et al. 1985), and mapped to a cylindrical equidistant projection. NASA level-2 normalised water radiances were generated from the SeawiFS data, and chl a concentration was determined using the SeaWiFS Data Analysis System (SeaDAS) and the OC4v4 algorithm (O'Reilly et al. 2000). These were then mapped to the same projection. Wind data were downloaded from an NOAA facility providing ocean surface wind speed and direction derived from the SeaWinds Scatterometer, available at http://orbit212.wwb.noaa.gov/quikscat/.

\section{RESULTS}

\section{Foraging trip length of equipped versus unequipped birds}

Foraging trip lengths were compared for equipped and unequipped birds breeding on Bird Island, Lambert's Bay. The mean duration of foraging trips was not significantly different between equipped birds $(x=13$ $\pm 8 \mathrm{~h}, \mathrm{n}=41)$ and control birds $(x=16 \pm 3 \mathrm{~h}, \mathrm{n}=10$ birds over 50 foraging trips in total; $t=-1.93 \mathrm{p}>0,05)$, although control birds tended to stay at sea for longer periods. There was no sign that devices impeded birds so as to increase their foraging time investment. All equipped birds returned to the nest with a load of fish and fed their chicks. Similar trials in northern gannets confirmed that gannets are apparently not handicapped by devices of this size (Garthe et al. 2000, Hamer et al. 2000).

\section{General foraging patterns}

We equipped 55 birds on Bird Island (Lambert's Bay), and 36 birds on Malgas with GPS loggers for single foraging trips (see example on Fig. 2). We recovered all of the devices and gathered a total of 584799 position fixes for birds foraging offshore. These positions were used to compile Figs. 3 \& 4 (see 'At-sea distributions'). Due to limited battery capacities, some of the foraging trips were not monitored completely. Our analysis of track characteristics as shown in Table 1 is based upon 41 and 26 complete trips recorded for birds foraging off Bird Island and Malgas, respectively. Among these birds, 10 individuals on Bird Island, and 5 on Malgas Island were fitted with time-depth recorders. Comparative foraging characteristics are given in Table 2. Overall, birds stayed at sea for foraging trips of between $1.5 \mathrm{~h}$ and $2 \mathrm{~d}$. During this period, they went 13 to $242 \mathrm{~km}$ away from the colony, covering a total of between 73 and $956 \mathrm{~km}$ (Fig. 2). When flying, their average travelling speed was 34 to $58 \mathrm{~km} \mathrm{~h}^{-1}$, with remarkable horizontal burst speeds of up to $118 \mathrm{~km} \mathrm{~h}^{-1}$. Birds fed during a series of dives initiated from the air (plunge-diving, Fig. 2), with 9 to 132 dives per foraging trip (Table 2), which lasted for a maximum of $22 \mathrm{~s}$ and reached a maximum depth of $9.7 \mathrm{~m}$. In total they spent $17 \mathrm{~s}$ to 12 min underwater per foraging trip. Birds did not only fly when at sea, but

Table 1. Morus capensis. Foraging path characteristics in Cape gannets from 2 neighbouring colonies. Sinuosity of path is the proportion of GPS speed to velocity (see 'Materials and methods'). Sinuosity and speed were used to discriminate foraging fixes (see 'Materials and methods'). Sample size $\mathrm{n}$ is the total number of birds equipped at each site, whereby each bird was equipped for a single foraging trip. Average values are given $\pm \mathrm{SD}$, along with maxima and minima when data were normally distributed. For non-normally distributed data, median values are given along with maxima and minima. Statistical differences between the 2 samples were tested using $t$-tests and $U$-tests (test statistic $W$ ) after data transformation, when appropriate. Significant statistical test results are indicated in bold

\begin{tabular}{|c|c|c|c|c|c|c|c|}
\hline & $\begin{array}{l}\text { Foraging trip } \\
\text { duration (min) }\end{array}$ & $\begin{array}{l}\text { Foraging path } \\
\text { length }(\mathrm{km})\end{array}$ & $\begin{array}{l}\text { Travelling speed } \\
\qquad\left(\mathrm{km} \mathrm{h}^{-1}\right)\end{array}$ & $\begin{array}{l}\text { Maximum distance } \\
\text { to colony }(\mathrm{km})\end{array}$ & $\begin{array}{l}\text { Sinuosity } \\
\text { of path }\end{array}$ & $\begin{array}{l}\text { Total time } \\
\text { flying (min) }\end{array}$ & $\begin{array}{l}\text { Number of } \\
\text { foraging fixes }\end{array}$ \\
\hline $\begin{array}{l}\text { Bird Island, } \\
\text { Lambert's Bay } \\
\mathrm{n}=41\end{array}$ & $\begin{array}{c}510 \\
y \quad(95-1766)\end{array}$ & $\begin{array}{c}228 \\
(73-571)\end{array}$ & $\begin{array}{c}44.3 \\
\pm 4.0 \\
(34.2-51.7)\end{array}$ & $\begin{array}{c}67 \\
\pm 39 \\
(13-152)\end{array}$ & $\begin{array}{c}1.1 \\
(1.02-1.32)\end{array}$ & $\begin{array}{c}355 \\
\pm 182 \\
(88-855)\end{array}$ & $\begin{array}{c}121 \\
\pm 79 \\
(18-353)\end{array}$ \\
\hline \multirow[t]{2}{*}{$\begin{array}{l}\text { Malgas, } \\
\text { Saldanha Bay } \\
n=26\end{array}$} & $\begin{array}{c}1356 \\
(200-2875)\end{array}$ & $\begin{array}{c}293 \\
(85-956)\end{array}$ & $\begin{array}{c}50.0 \\
\pm 3.4 \\
(44.1-58.3)\end{array}$ & $\begin{array}{c}104 \\
\pm 59 \\
(17-242)\end{array}$ & $\begin{array}{c}1.4 \\
(1.0-1.85)\end{array}$ & $\begin{array}{c}466 \\
\pm 166 \\
(160-946)\end{array}$ & $\begin{array}{c}252 \\
\pm 202 \\
(45-728)\end{array}$ \\
\hline & $\begin{array}{l}W=1127 \\
p<0.001\end{array}$ & $\begin{array}{l}W=1203 \\
p=0.014\end{array}$ & $\begin{array}{l}t=-6.23 \\
p<0.001\end{array}$ & $\begin{array}{r}\boldsymbol{t}=-2.78 \\
\mathbf{p}=\mathbf{0 . 0 0 8}\end{array}$ & $\begin{array}{c}W=1318 \\
\mathbf{p}=\mathbf{0 . 0 0 5} \\
\text { inus-transformed) }\end{array}$ & $\begin{array}{l}t=-2.57 \\
p=0.013\end{array}$ & $\begin{array}{c}t=-3.15 \\
p=0.004\end{array}$ \\
\hline
\end{tabular}




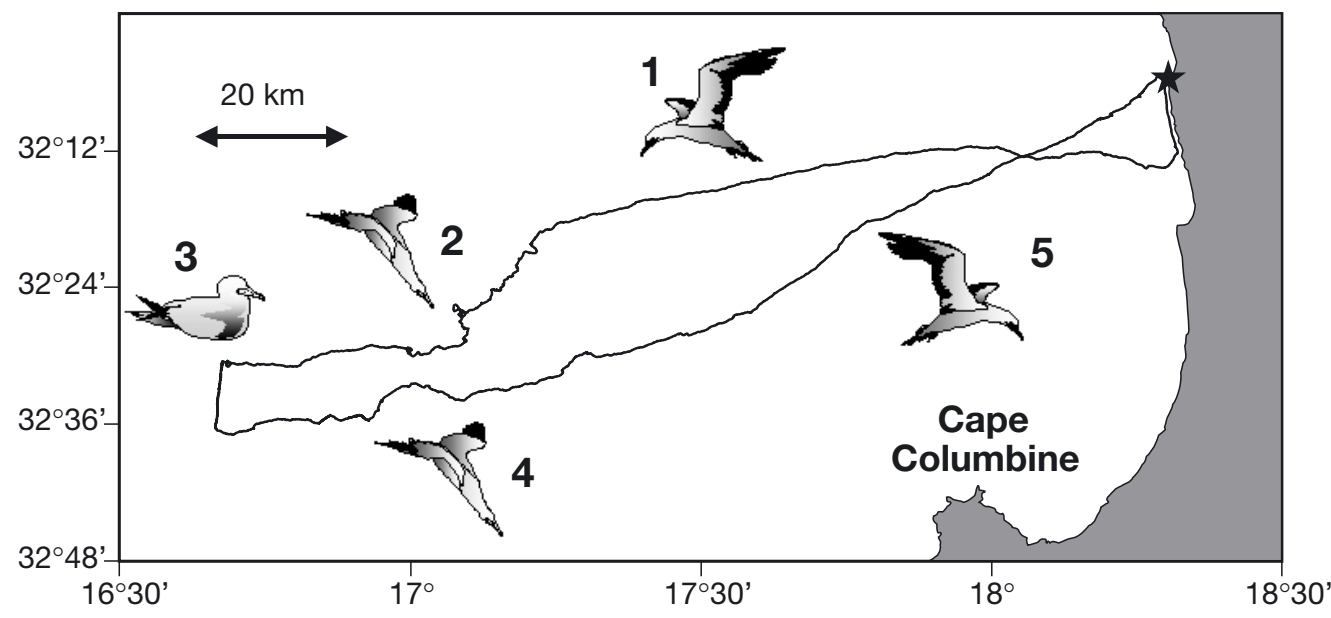

Fig. 2. Morus capensis. Example of GPS track recorded at $10 \mathrm{~s}$ intervals for a Cape gannet foraging off Lambert's Bay. The feeding trip can be divided in 5 consecutive sections (see Ropert-Coudert et al. 2004b). (1) The bird commutes between the coast and potential feeding ground (high absolute and relative speed, low sinuosity). (2) It feeds by repeated plungediving, and circling over profitable zones (low relative speed, high sinuosity). (3) It rests at the sea surface, where it drifts with the current. (4) The bird feeds again, $16^{\circ} 30^{\prime}$

$17^{\circ} 30^{\prime}$

$18^{\circ} 30^{\prime}$ before (5) flying back to the colony

also rested at the sea surface for ca. $53 \%$ of the total time away from the colonies. This proportion varied widely between individuals ( 7 to $76 \%$ ). The overall sinuosity of the foraging paths was always $<2$, indicating a high proportion of linear movements. Birds there- fore travelled extensively to target a limited number of foraging patches: using the algorithm described in the methods we identified only ca. $3.4 \%$ (range 0.6 to $24.9 \%$ ) of at-sea locations as being associated with feeding activity (termed 'foraging fixes' in Table 1).
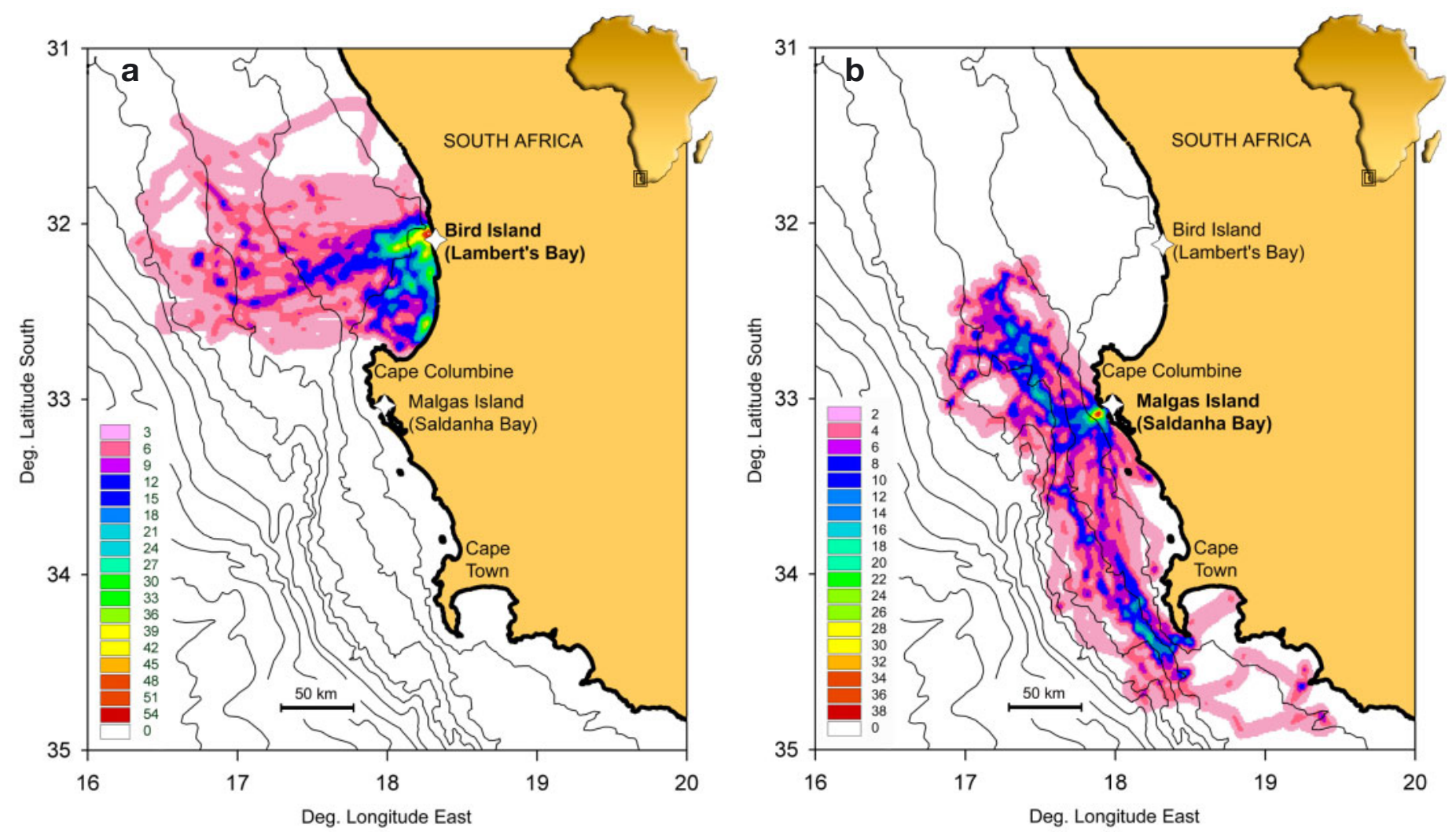

Fig. 3. Morus capensis. (a) Density distribution of 288562 positions recorded for 55 Cape gannets foraging off Bird Island, Lambert's Bay, using GPS loggers. The contour plots show the density of positions on a $0.01^{\circ}$ grid (i.e. $1.11 \times 0.94 \mathrm{~km}$ ). See colour scale for data densities per unit area, and methods section for details on data handling. Bathymetry is indicated by isobaths set at $100 \mathrm{~m}$ depth intervals. This representation shows that gannets breeding in Lambert's Bay utilize the shelf area $(<500 \mathrm{~m})$ situated west-southwest of the colony, but do not forage south of Cape Columbine. (b) Density distribution of 282789 positions recorded for 36 Cape gannets foraging off Malgas using GPS loggers. See (a) for conventions. This representation shows that gannets breeding on Malgas utilise the shelf area $(<500 \mathrm{~m})$ between Cape Columbine and Danger Point, seldom foraging north of Cape Columbine. Areas of high data density indicate zones within which birds spend extensive time periods, either commuting, actively foraging, or resting at the water surface 
Results grouped by colony clearly show that birds from Malgas had a significantly higher foraging investment than birds from Bird Island (Table 1). Malgas birds stayed at sea for longer periods, travelling farther with a longer foraging path. They also spent longer periods flying, and visited a higher number of foraging sites. Their sinuosity index was higher, indicating that they spent a higher proportion of the foraging trip searching for food. Surprisingly, even the average travelling speed was significantly higher for birds from Malgas, suggesting that their average mechanical effort was substantial. Average speed increased significantly with increasing maximum foraging distance (Bird Island: $\mathrm{r}^{2}=0.28, F_{1,39}=15.31, \mathrm{p}<0.001$; Malgas: $\left.\mathrm{r}^{2}=0.36, \quad F_{1,24}=13.49, \mathrm{p}=0.001\right)$, and with increasing foraging path (Bird Island: $\mathrm{r}^{2}=0.16$, $F_{1,39}=7.4, \mathrm{p}=0.01$; Malgas: $\mathrm{r}^{2}=0.28, F_{1,24}=9.65$, $\mathrm{p}=0.005)$.
Table 2. Morus capensis. Plunge-diving behaviour of Cape gannets from 2 neighbouring breeding colonies. Dive duration and maximum depth per dive were averaged over entire foraging trips. Maximum sample size $\mathrm{n}$ is the total number of birds equipped at each site, whereby each bird was equipped for a single foraging trip. Average values are given $\pm \mathrm{SD}$, along with maxima and minima. Statistical differences between the 2 samples were tested using $t$-tests

\begin{tabular}{|lcccc|}
\hline & $\begin{array}{c}\text { Number of } \\
\text { dives per } \\
\text { trip }\end{array}$ & $\begin{array}{c}\text { Dive } \\
\text { duration } \\
(\mathrm{s})\end{array}$ & $\begin{array}{c}\text { Maximum depth } \\
\text { per dive } \\
(\mathrm{m})\end{array}$ & $\begin{array}{c}\text { Total dive } \\
\text { time per trip } \\
(\mathrm{s})\end{array}$ \\
\hline Bird Island, & 66 & 4.3 & 3.6 & 256 \\
Lambert's Bay & \pm 41 & \pm 1.4 & \pm 1.0 & \pm 144 \\
$\mathrm{n}=10$ & $(14-132)$ & $(2.2-7.1)$ & $(2.2-5.6)$ & $(95-455)$ \\
Malgas, & 68 & 4.3 & 3.4 & 343 \\
Saldanha Bay & \pm 51 & \pm 1.6 & \pm 1.1 & \pm 303 \\
$\mathrm{n}=5$ & $(9-117)$ & $(1.9-6.5)$ & $(1.6-4.3)$ & $(17-761)$ \\
& $\boldsymbol{t}=\mathbf{- 0 . 0 5}$ & $\boldsymbol{t}=\mathbf{0 . 0 1}$ & $\boldsymbol{t}=\mathbf{0 . 3 8}$ & $\boldsymbol{t}=\mathbf{- 0 . 6 1}$ \\
& $\mathbf{p}>\mathbf{0 . 0 5}$ & $\mathbf{p}>\mathbf{0 . 0 5}$ & $\mathbf{p}>\mathbf{0 . 0 5}$ & $\mathbf{p}>\mathbf{0 . 0 5}$ \\
\hline
\end{tabular}

Our results also show that foraging trip duration is positively correlated with maximum foraging distance (Bird Island: $\mathrm{r}^{2}=0.75, F_{1,39}=116.94, \mathrm{p}<0.001$; Malgas: $\left.\mathrm{r}^{2}=0.36, F_{1,24}=13.25, \mathrm{p}=0.001\right)$, as well as with foraging path length (Bird Island: $\mathrm{r}^{2}=0.83, F_{1,39}=190.86$, $\mathrm{p}<0.001$; Malgas: $\left.\mathrm{r}^{2}=0.65, F_{1,24}=45.79, \mathrm{p}<0.001\right)$.
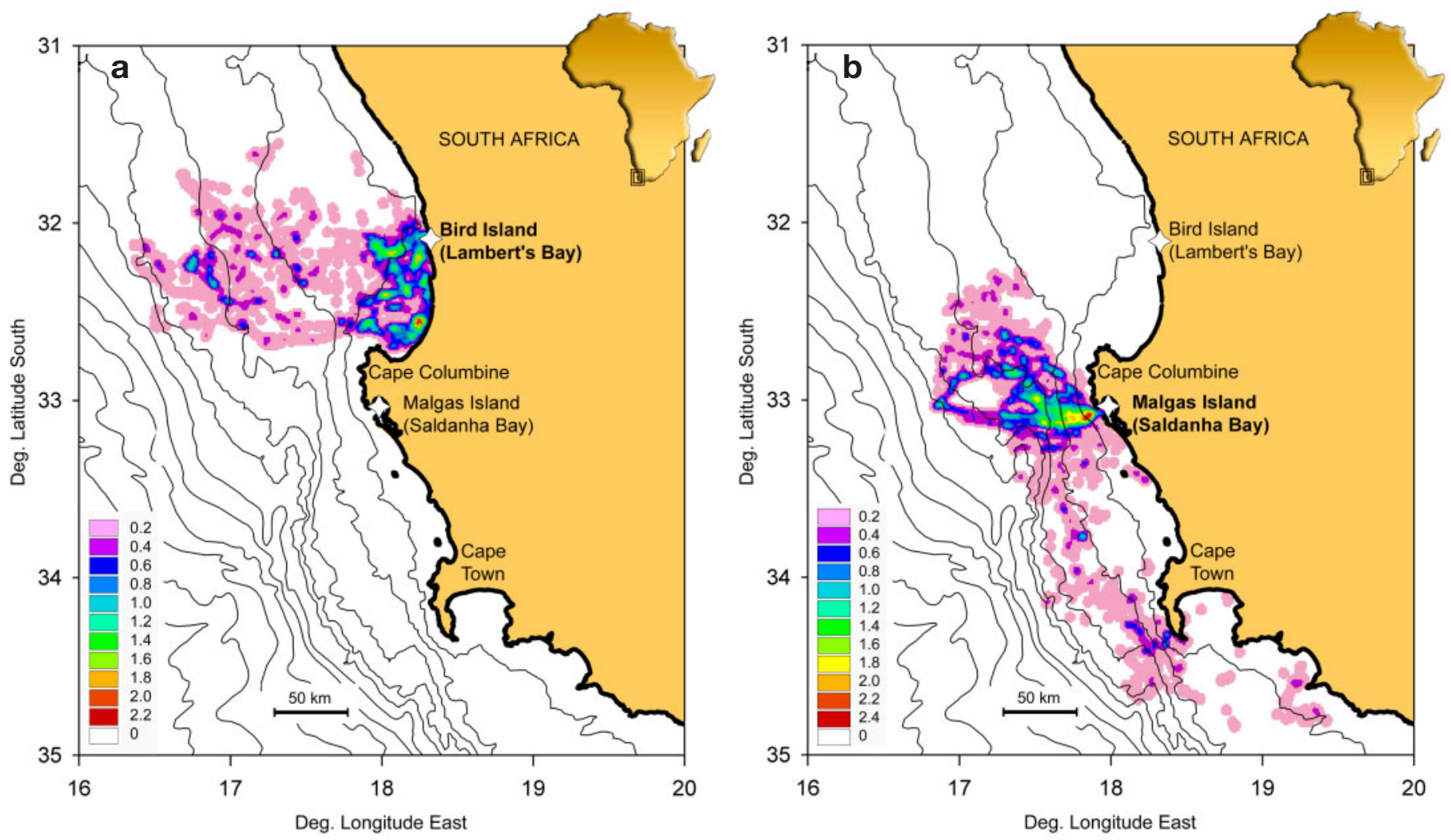

Fig. 4. Morus capensis. (a) Density distribution of 6091 positions associated with feeding activity (see 'Materials and methods') recorded for 55 Cape gannets foraging off Bird Island, Lambert's Bay, using GPS loggers. See legend of Fig. 3a for conventions. This representation shows that gannets breeding on Bird Island utilise the shelf area $(<500 \mathrm{~m})$ situated west-southwest of the colony, but do not forage south of Cape Columbine. (b) Density distribution of 7357 positions recorded for 36 Cape gannets foraging off Malgas using GPS loggers. This representation show that gannets breeding on Malgas utilise the shelf area $(<500 \mathrm{~m})$ between Cape Columbine and Danger Point, seldom foraging north of Cape Columbine 
Interestingly, no significant differences were found between the diving effort and the diving behaviour of birds from either group (Table 2).

\section{At-sea distributions}

The foraging ranges of Cape gannets from Bird Island and Malgas, compiled using all at-sea positions, overlapped very little (Fig. 3). For gannets from Bird Island the foraging area is roughly confined to a $200 \times$ $150 \mathrm{~km}$ rectangle adjacent to the Atlantic coast line (approximate total surface $20900 \mathrm{~km}^{2}$ ). By comparison, birds from Malgas exploit a much narrower coastal zone of 75 to $100 \mathrm{~km}$ width, linked to the narrower continental shelf in this region, stretching mainly south of the breeding site, over a total length of ca. $400 \mathrm{~km}$ (approximate total surface $21500 \mathrm{~km}^{2}$ ). Both foraging zones are contained by the $500 \mathrm{~m}$ isobath. Limiting the ranges to locations associated with feeding activity results in a similar general distribution, with markedly smaller total foraging zones (approximately $13100 \mathrm{~km}^{2}$ and $14700 \mathrm{~km}^{2}$ for individuals from Bird Island and Malgas, respectively; Fig. 4). In this case both foraging areas are skewed towards the south. The 'hot spots' of location fixes displayed on Fig. 4 are different from those shown on Fig. 3. This is due to the fact that in the former, large numbers of fixes were accumulated for areas within which birds commuted and/or rested for extended periods at the sea surface. Such commuting and resting areas are excluded from Fig. 4, which therefore only shows the preferred feeding areas of the birds.

The most striking feature is the limited overlap of both foraging zones. This overlap represents ca. 14 and $13 \%$ of the total sea area (Figs. 3 \& 5) used by Cape gannets from Bird Island and Malgas, respectively, and ca. 13 and $11 \%$ of their respective foraging areas (Figs. 4 \& 5). This contrasts with the theoretical overlap of foraging areas calculated using a $350 \mathrm{~km}$ foraging range $(89 \%$ for Bird Island and $63 \%$ for Malgas, Fig. 5), or the colony-specific foraging range and the $500 \mathrm{~m}$ isobath $(93 \%$ for Bird Island and $67 \%$ for Malgas, Fig. 5), which show a high level of theoretical overlap, confirming that birds from both colonies coexploit closely related theoretical foraging areas.

\section{Link with abiotic parameters}

All birds foraged within the core of the southern Benguela upwelling zone (Figs. 6 \& 7). During the study period, active upwelling occurred along the length of the coast, being most intense and concentrated in 3 dynamic upwelling cells visible off the Cape Peninsula, Cape Columbine, and Hondeklip Bay. The

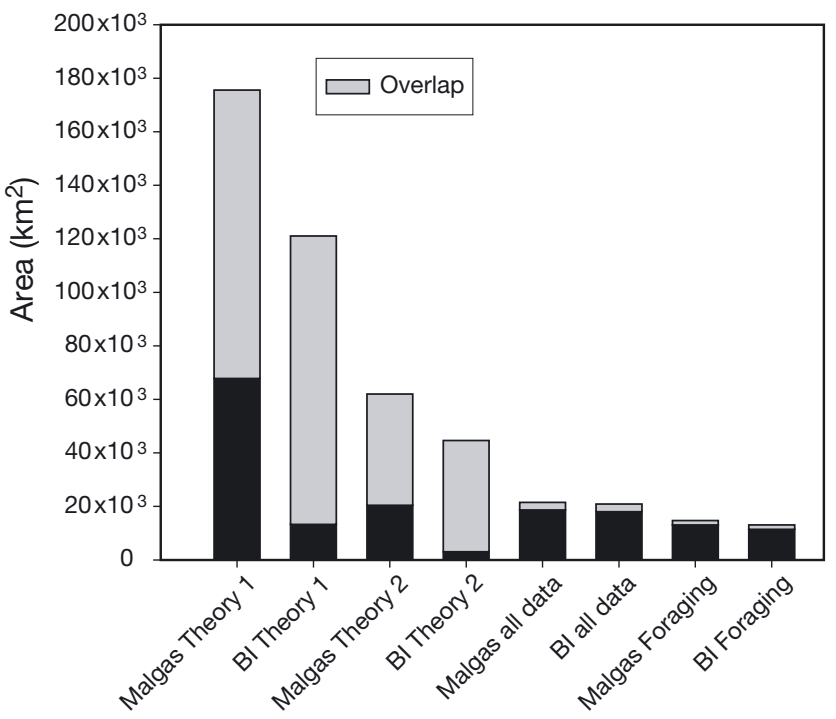

Fig. 5. Morus capensis. Different estimates of foraging areas for the 2 breeding colonies (Malgas = Malgas Island, BI = Bird Island). Theory 1 is the theoretical foraging area calculated using a $350 \mathrm{~km}$ radius, Theory 2 is the theoretical foraging area calculated using the measured foraging range and the $500 \mathrm{~m}$ isobath. 'All' is the foraging area calculated using all positions recorded outside of the colony, and 'Foraging' is the foraging area calculated using filtered positions associated to active foraging (see 'Materials and methods' for details). Note that the foraging areas based on field data are much smaller, and overlap far less than expected from theory

seaward boundary of upwelled waters was clearly defined and the boundary of high chlorophyll concentration waters clearly co-incident with the offshore thermal front. Maximum phytoplankton concentrations occurred 20 to $80 \mathrm{~km}$ offshore, although blooms following periods of active upwelling eventually extended $100 \mathrm{~km}$ or more offshore. Chl a concentrations in recently upwelled water, maturing upwelled water and aged water were $<1,1$ to 20 and 5 to $30 \mathrm{mg}$ $\mathrm{m}^{-3}$, respectively. Primary production in the Benguela ecosystem is similar to that in the Humboldt system off Chile and Peru, and substantially greater than off California. Average primary production estimates for the northern Benguela are 1.2 and $2.0 \mathrm{gC} \mathrm{m}^{-2} \mathrm{~d}^{-1}$ for the southern Benguela (Brown et al. 1991).

The southern Benguela is characterised by prevailing south-easterly winds during the austral summer, which were clearly dominant throughout the study period (Fig. 8). Wind speeds recorded within both foraging areas during the study periods were significantly different (Bird Island: median $=7.7 \mathrm{~m} \mathrm{~s}^{-1}$; Malgas: median $=15 \mathrm{~m} \mathrm{~s}^{-1} ; W=550, \mathrm{p}=0.0065$ ), with winds being markedly stronger off Malgas. These tendencies are also clearly marked in the long term (Nelson 1992, Blanke et al. 2002). 


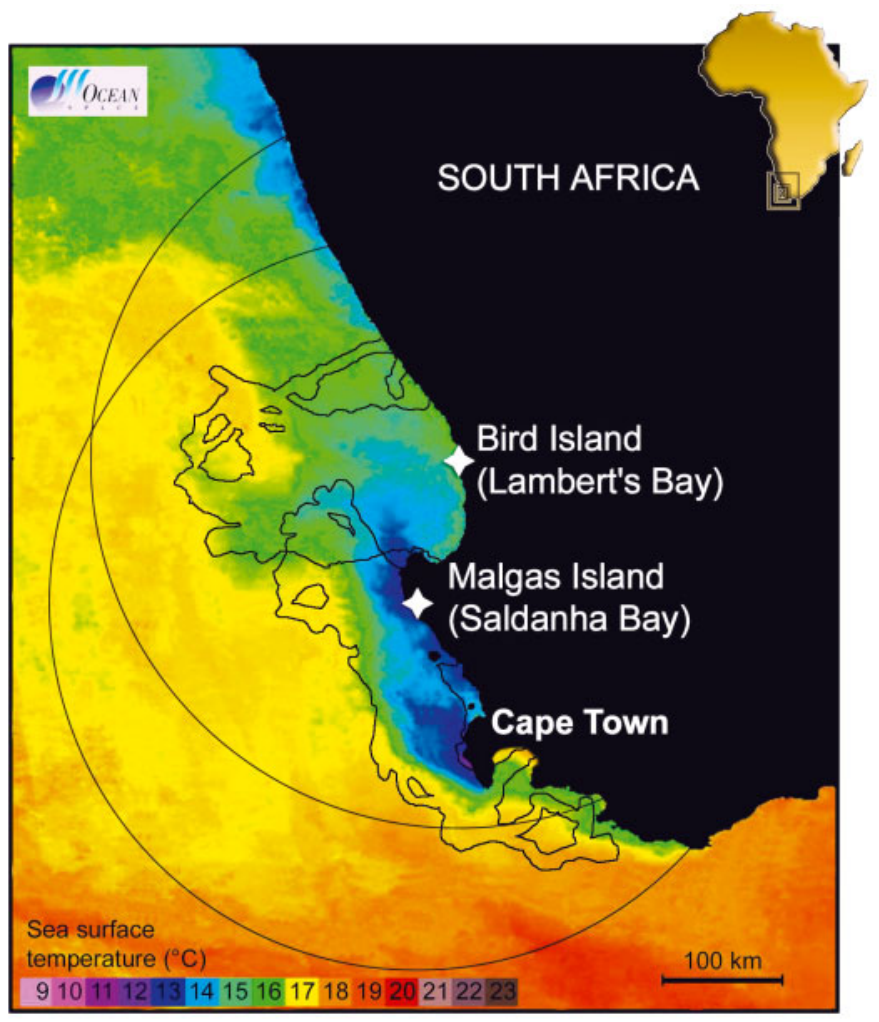

Fig. 6. Morus capensis. Sea surface temperatures off southern Africa during our study period (December 2002). Contours of the home ranges of Cape gannets foraging off Lambert's Bay and Malgas are shown, as well as their maximum theoretical foraging area based on the recorded maximum foraging ranges. Note that birds preferentially forage within the southern core of the Benguela upwelling zone (see 'Results')

\section{DISCUSSION}

Most seabirds live cryptic offshore lives, only spending a small proportion of their time on land to raise their offspring (Schreiber \& Burger 2002). Consequently, until some $20 \mathrm{yr}$ ago, very little was known about how seabirds function in the marine environment (Ainley 1980). Since then the explosive development of microchip technologies has boosted the field of wildlife telemetry, especially for the study of large marine animals (Croll et al. 1998, Wilson et al. 2002). Technologies enabling the localization of animals at sea have been developing at an ever faster pace. In seabirds, such techniques now range from conventional VHF radio-tracking to GPS tracking, via global location based on light levels and satellite tracking (review in Wilson et al. 2002). These different applications all have strengths and weaknesses, and might find valuable applications under different field conditions. However, the recent miniaturisation of GPS recorders <100 g (Bürgi \& Werffeli 1999, Steiner et al. 2000, von Hünerbein et al. 2000), and the possibility to

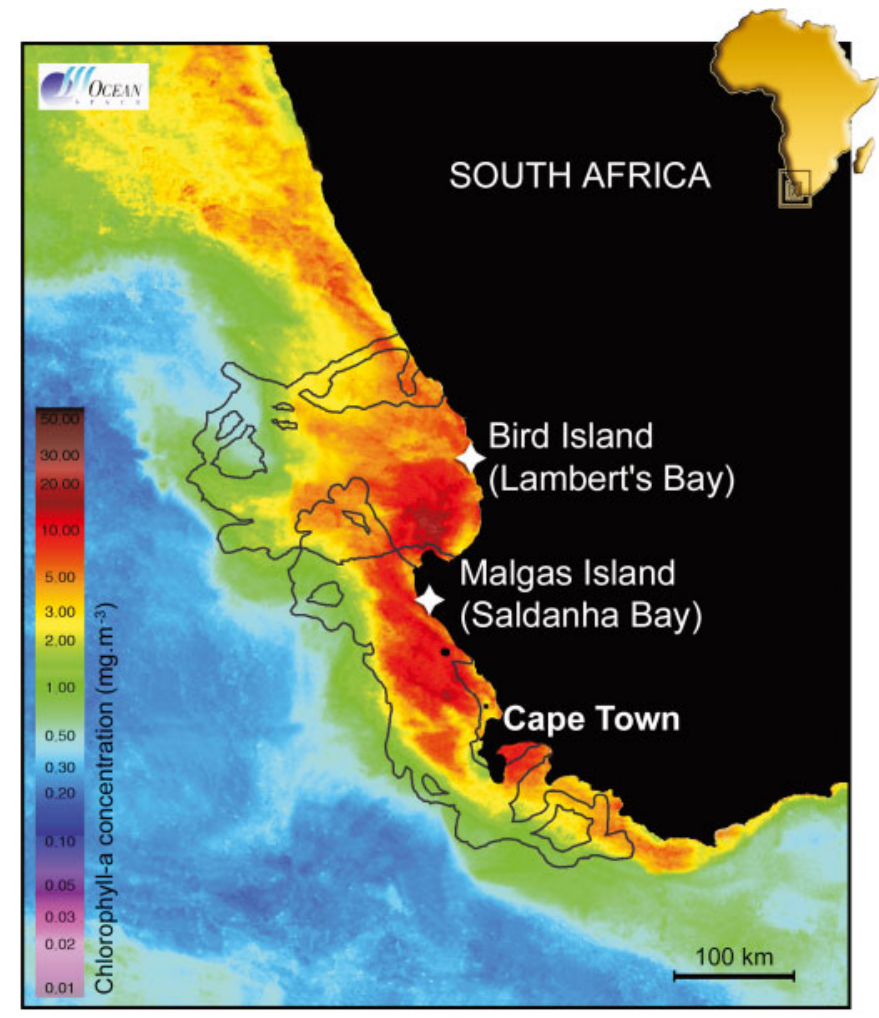

Fig. 7. Morus capensis. Chl a concentration at the sea surface off southern Africa during our study period (December 2002). Contours of the home ranges of Cape gannets foraging off Lambert's Bay and Malgas are shown. Note that birds preferentially forage within the southern core of the Benguela upwelling zone (see 'Results')

deploy them on a wide range of bird species (Biro et al. 2002, Weimerskirch et al. 2002) is likely to revolutionise our knowledge of how seabirds utilise the marine environment. GPS recorders have 2 major advantages when compared with other tracking systems. Firstly they provide an unprecedented positional accuracy, with position errors of within $\pm 5 \mathrm{~m}$ in $90 \%$ of cases. This allows animal movements to be tracked at a very fine scale. Secondly, position and speed of the animal can be recorded at any given interval from 1 to $x$ seconds. Currently, the lightest GPS module weighs only $27 \mathrm{~g}$, a mass which is likely to decrease rapidly in the future. However, power consumption required for satellite uplinks and data storage is still substantial, and therefore battery size and total recording capacity are often the limiting factors. During the present study, we took advantage of the fact that Cape gannets conducted relatively short foraging trips (compared with other seabird species; breeding king penguins can for example stay at sea for up to several weeks; Adams 1987 ) to record the movements of the animals every $10 \mathrm{~s}$ during entire foraging trips. We use this valuable data set to compare the foraging ecology of Cape gan- 


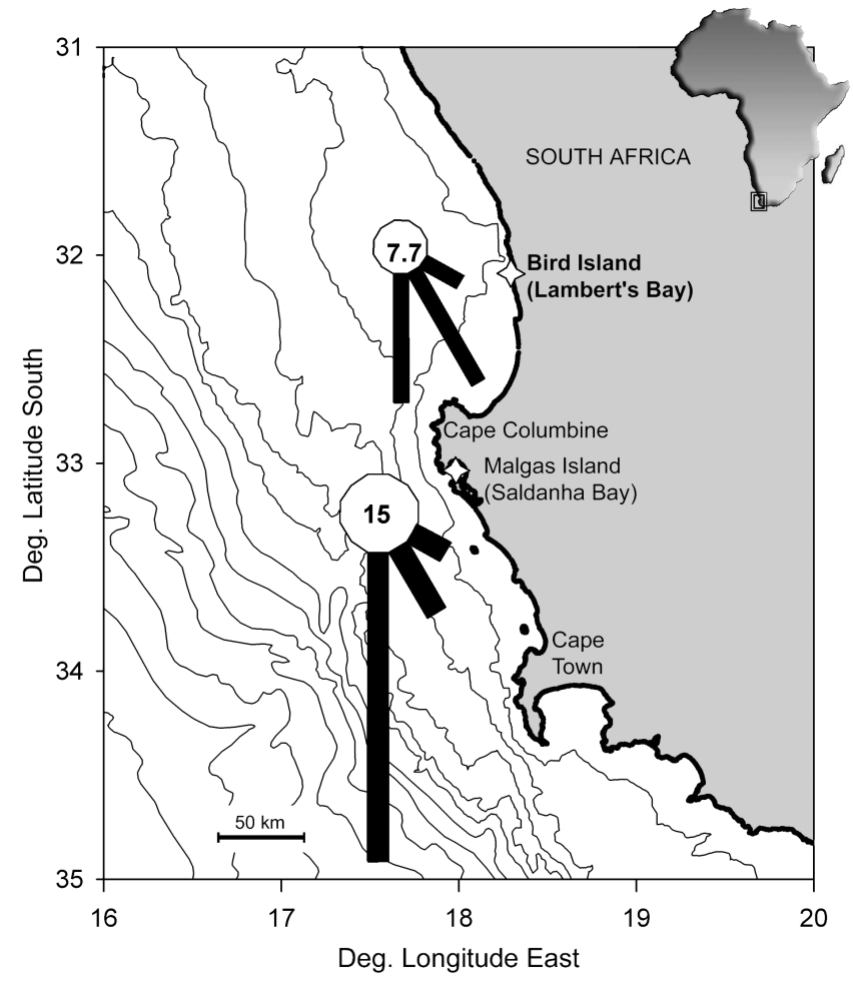

Fig. 8. Morus capensis. Southern part of the Benguela zone, which is characterized by strong, prevailing southerly winds. Wind roses (circular shapes) show the predominant wind directions during the study period (December 2002). The median wind speed in each area is indicated in $\mathrm{m} \mathrm{s}^{-1}$ in the middle of each wind rose

nets from the 2 neighbouring colonies in an attempt to understand how they exploit and share the available foraging space.

\section{Hypothesis 1: The foraging areas of neighbouring colonies widely overlap}

Our results do not support this prediction. We found a maximum foraging range of ca. $150 \mathrm{~km}$ and $240 \mathrm{~km}$ for birds from Bird Island and Malgas Island, respectively, and these breeding sites are only $110 \mathrm{~km}$ apart. This confirms that, in theory, birds from both colonies have the capacity to display widely overlapping foraging areas (see Figs. 5 \& 6). There was nonetheless a clear discrimination of foraging areas (Figs. $3 \& 5$ ) and of feeding zones (Figs. $4 \& 5$ ) between the 2 sites, suggesting that birds from either site chose different foraging options.

It might be argued that our field measurements were conducted over a limited period of a single breeding season, and therefore highlight an atypical, ephemeral pattern. This is unlikely to be the case because our measurements confirm a long-suspected segregation of foraging areas between gannets from the 2 islands. After the wreck of the oil tanker 'Castillo de Bellver' off Saldanha Bay in 1979, Berruti noticed that only gannets from Malgas Island were oiled. In following years, he organised colour-marking experiments which confirmed that birds from Bird Island tend to forage north of Cape Columbine, whereas birds from Malgas largely remain south of this virtual boundary (Berruti 1987). Subsequently, Adams and colleagues conducted an extensive radio-tracking study of Cape gannets from Malgas (Adams \& Navarro in press). This study, conducted on $>200$ breeding birds throughout 3 breeding seasons, highlighted a similar trend. Finally, recent satellite tracking of birds from both sites also confirmed this pattern (Crawford et al. unpubl. data). There is thus substantial evidence that this foraging segregation (Figs. 3, 4 \& 5) is consistent through time. We propose several, mutually non-exclusive explanations for this phenomenon.

\section{Distribution of food resources}

Our study confirms that Cape gannets are closely linked to the shelf areas of less than $500 \mathrm{~m}$. This shelf zone is relatively narrow off southern Africa, and favours, along with strong southerly winds and associated currents, some intense upwelling movements (Figs. $6 \& 7$ ). These features enhance primary and secondary production, and the populations of pelagic fish benefiting from them (Shannon 1985, Lutjeharms et al. 2001, Shannon et al. 2003). Like several other seabird species in the area (mainly Cape cormorants Phalacrocorax capensis and African penguins Spheniscus demersus) Cape gannets target fish in the southern part of the Benguela upwelling system. As the shelf is more than twice as wide off Bird Island than off Malgas (Figs. 3, $6 \&$ 7), birds attending the former colony have access to a wider foraging zone than birds from the latter, which face a narrow foraging corridor. This explains why the foraging area from the former is skewed towards the west, whereas in the latter case it stretches along an approximate north-south axis.

There is a ca. 4-fold difference in colony size between the 2 sites. As the total foraging zone for birds from Malgas is similar to that for Bird Island, the theoretical average gannet density within this zone should therefore be 4 times higher than within the area utilised by birds from Bird Island. Consequently, within the overlapping zone of both foraging areas the theoretical average density should be 1.25 times higher than for the area 'Malgas only' and 5 times higher than for the area 'Bird Island' only. This simplistic approach is unlikely to reflect the field situation 
because it assumes a uniform distribution of predators and resources. This is certainly not the case within the study area (Figs. 3, 4, $6 \&$ 7). The area off Cape Columbine might nonetheless feature a boundary zone of high predator density, which could deter foraging individuals. However, it is surprising that some birds from Malgas fly $240 \mathrm{~km}$ south-west, past the Cape of Good Hope, although the intense foraging activity of conspecifics from Bird Island indicate that there are highly profitable prey patches within $50 \mathrm{~km}$ (Fig. 4a). These profitable patches lie within well-known nursery areas for pelagic fish, in the St. Helena Bay area (east of Cape Columbine, Hutchings 1992). Knowing the high field metabolic rates of Cape gannets (Adams et al. 1991), it is unlikely that competition avoidance alone can stimulate Cape gannets to commute an additional $400 \mathrm{~km}$ to feed.

\section{Cultural effects}

Foraging animals do not exploit their environment in a uniform manner, and skewed foraging patterns have been recorded for several species, both in the wild and in the laboratory (Portha et al. 2002). Such asymmetries are usually linked to heterogeneities within the distribution of food resources (Hölldobler 1976). The pelagic fish stocks targeted by Cape gannets are not evenly distributed through time and space. They rather occur in ephemeral patches (Crawford et al. 1987). Such patchiness might explain the preferences of birds for specific 'hot spots' (see Fig. 4), but not the recurrent skewed patterns described above. Skewed foraging patterns can also occur independent of food distribution. In such cases they are thought to be related to the intrinsic dynamics of group-foraging (Boinski \& Garber 2000, Portha et al. 2002). This hypothesis speculates the existence of spontaneous, self-organised asymmetries that might occur through a snowball effect when animals forage in hierarchical groups.

Cape gannets fly in formation when they commute between the breeding colony and the feeding grounds. Such line or V-formations can gather up to 100 birds (Nelson 1978) saving energy when flying long distances (Weimerskirch et al. 2001). Group members might also capitalise on a leading individual, on its capacities to locate prey patches and to relay this information to conspecifics (Barta \& Giraldeau 1998, Drapier et al. 2002). In practice, if one formation leader from Malgas chooses to fly south when leaving Saldanha Bay, this might influence the foraging decision of 100 conspecifics. Knowing that approximately 30000 Cape gannets fly off Malgas every single day during the breeding season, searching for food, this gives in theory the potential for at least 300 formations. If such formations tend to depart in different directions, the self-organisation hypothesis does not hold. If, however, such formations also tend to observe and follow each other, this could catalyse foraging area asymmetries. Although such mechanisms still need to be investigated in detail, at-sea observations show that gannets do tend to observe each other at sea, and to rush towards existing feeding aggregations (Nelson 1978, Camphuysen \& Webb 1999). The birds' conspicuous white plumage colour and spectacular plunge-diving behaviour is likely to play a major role in this signalling process (Nelson 1978). Beyond this snowball effect, the fidelity of seabirds to certain feeding places might also favour skewed foraging distributions. Seabirds, gannets in particular, have shown fidelity to specific foraging areas that they visit repeatedly (Grémillet et al. 1999, Hamer et al. 2001). If such memory effects build onto skewed foraging areas generated by group foraging, it is legitimate to expect the emergence of 'cultural foraging patterns' within a seabird population, especially if this population shows high longevity, and extensive philopatry (as it is the case for gannets, Nelson 1978). This strategy enables birds to gather intimate knowledge of a specific foraging zone, foraging trip after foraging trip, year after year.

\section{Wind patterns and energy-efficient foraging}

Although group dynamics might play a role in the segregation of foraging zones we think that Cape gannets might also be sensitive to more prosaic constraints.

Foraging investment in terms of flying effort is a major currency for gannets (Birt-Friesen et al. 1989). Cape gannets can save energy by flying in formation, but also by using wind patterns. They can soar when flying across-wind, but they can also gain substantial speed by flying with the wind. It is striking that birds mainly foraged south-southwest of their breeding colonies, and therefore flew back to the nest with the prevailing southerly winds, reaching over-ground speeds of $>100 \mathrm{~km} \mathrm{~h}^{-1}$ (Fig. 1). This may help birds to save substantial amounts of energy, especially because they carry an additional food load for the chick. Because southerly winds are recurrent in the Benguela (Nelson 1992, Blanke et al. 2002), we suggest that Cape gannets breeding in the area developed a strategy to minimise their transport costs by exploiting foraging grounds situated to the south of their breeding grounds. As shown in Figs. 3 \& 4, birds from both colonies tend indeed to favour southern destinations when foraging. This tendency is stronger for birds breeding on Malgas, which might be partly due to the shape of the shelf zone (see above), but also to the stronger southerly 
winds in this zone (Fig. 8). This strategy might also be supported by the fact that coastal winds follow a diurnal, thermic-driven rhythm, with wind speeds increasing through the day. As Cape gannets tend to start from the colony in the early morning, and fly back in the evening, they are likely to depart with low head wind, and return with strong tail winds.

\section{Hypothesis 2: The foraging effort of birds from neighbouring colonies does not differ}

Our data also contradict this prediction, as they show that birds from the larger breeding site (Malgas) worked significantly harder than individuals from the smaller colony (Table 1). Birds from Malgas foraged farther and travelled for longer periods at higher speed to visit a larger number of feeding patches. These results comply with previous studies indicating that density-dependent effects play an important role in shaping seabird populations (Ashmole 1963, Lewis et al. 2001) However, they did not dive more often than birds from Bird Island. In our opinion, this is linked to the fact that gannets locate prey from the air, where they decide to initiate plunge-diving, or to travel to the next prey patch. If a bird decides to target a prey patch, its predatory success is then close to $100 \%$. Birds from Malgas had to scan a larger area before they found appropriate feeding grounds. We suggest that they joined existing feeding aggregations sighted from a distance, but that in many cases these aggregations were already too crowded with conspecifics to be profitable (Camphuysen \& Webb 1999).

Marked differences in the foraging investment between the 2 colonies, along with the discrimination of their foraging grounds, show that the 2 colonies function as independent breeding sites. There was nonetheless no proportional increase of foraging area, and foraging effort with colony size, i.e. the former characteristics did not show a 4 -fold variation between the 2 sites (Table 1, Figs. 3 \& 5). This suggests that the zone utilised by gannets from Malgas might have been slightly more profitable than the zone north of Cape Columbine. Remote-sensed sea surface temperatures do show intense upwelling activity within the foraging area of Malgas birds (i.e. off Saldanha Bay and the Cape Peninsula) during the study period (Figs. 6 \& 7). However, there is a time lag between strong upwelling activity and enhanced primary production (compare Figs. $6 \& 7$ ), and the availability of pelagic fish does not show a straightforward, linear response to these parameters. It is therefore difficult to tell whether feeding conditions might have been better south of Cape Columbine. Current data rather indicate that pelagic fish are abundant throughout the zone used by Cape gannets from both colonies (Naidoo \& Verheye 2001).

Relatively good feeding conditions for birds from Malgas are also underlined when comparing our results with those of recent investigations in northern gannets from the British Isles (Hamer et al. 2000, 2001). These show that birds from the Bass Rock colony (similar size as the Malgas colony, i.e. 70000 breeding pairs) make longer foraging trips (31 to $32 \mathrm{~h}$ on average), travel farther (average foraging range 220 to $230 \mathrm{~km}$ ), over a much larger foraging area $\left(>200000 \mathrm{~km}^{2}\right)$, than birds from Malgas. Such comparison indicates that pelagic fish resources are less available to northern gannets foraging in the North Sea, than to Cape gannets feeding in the Benguela. In the North Sea the populations of mackerel Scomber scombrus, herring Clupea harengus and sandeel Ammodytes marinus upon which northern gannets prey (Wanless 1984) are critically depleted, or under great pressure from industrial fisheries (Serchuk et al. 1996). Contrarily, in the Benguela, anchovy and sardine populations largely recovered from the spectacular crashes of the 1980s, and now show important recruitment, especially since 1999 (Naidoo \& Verheye 2001).

\section{OUTLOOK}

Our study suggests the existence of cultural factors in the foraging decisions of seabirds from different breeding sites. Although very little is known about these features, similar patterns have been also highlighted in other seabird species (Weimerskirch et al. 1988, Huin 2002). The mechanisms of such cultural patterns, and the relative importance of biotic factors (prey distribution), abiotic factors (wind patterns), and group dynamics onto their emergence remain to be investigated. Further important features, such as sexspecific foraging decisions, which have been recently shown in northern gannets (Lewis et al. 2002), will also need to be considered.

The aim of this paper was to analyse the impact of coloniality and intra-specific competition for food in a seabird species. To this end we considered an appropriate single-species model. However, we are aware of the fact that the actual natural situation might be far more complex. Beyond Cape gannets, the Benguela also supports vast populations of cormorants, penguins, marine mammals (e.g. fur seals Arctocephalus pusillus pusillus), and predatory fish (e.g. snoek Thyrsites atun). The gannets' extensive travelling capabilities and specific prey-catching techniques provide them with a highly specialised and successful ecological niche. However, it is clear that gannets will also interact with other end consumers. Such inter-specific relationships might be negative (competition for food), 
but also positive: gannets, which only target fish within the top $10 \mathrm{~m}$ of the water column, might benefit from collaborative feeding with deeper-diving seabirds such as cormorants and penguins (Camphuysen \& Webb 1999), or from interactions with marine mammals and predatory fish, which drive fish shoals towards the surface (BBC 2001; see also Pitman \& Ballance 1992). Finally, gannets might compete with fisheries, and/or benefit from fish discards and offal dumped by fishing vessels (although the latter effect is still minor in Cape gannets, at least during the breeding season; Crawford et al. unpubl. data, cf. Burger \& Cooper 1984).

It is the complex interplay of such intra- and interspecific competition with environmental variability and abiotic forcing which shapes the foraging modes of seabirds such as Cape gannets in the Benguela.

Acknowledgements. This collaborative project was funded by a joint fellowship of the Direction des Affaires Internationales du CNRS and of the South Africa National Research Foundation to D.G. and P.G.R. We are grateful for the support of the Swiss National Research Foundation and the NCCR Neural Plasticity and Repair through Prof. Lipp, the Japanese Polar Institute through Prof. Naito, the BBC through T. Dorrity, the SeaWiFS Project at the NASA Goddard Space Flight Centre, Cape Nature Conservation and South African National Parks. Technological development of the GPS log was made possible via the IMPRESS project funded by the European Community (coordinated by K. Camphuysen). Prof. Knöchel, Institute for High-Frequency Engineering, Technical Faculty University Kiel, provided G.P. with access to some of his metrology and infrastructure. C. Cilliers, S. Petersen, L. Upfold, L. Staverees, $\mathrm{O}$. Curtis and the wardens at Bird Island and Malgas helped during the field sessions. C. Moloney, J. Cooper, R. Navarro, C. Chauvin, Y. Le Maho, R. Crawford, M. DuPlessis and S. Wanless provided support at different stages of this work, and were available for fruitful discussions. D. Michard-Picamelot, W. Hirsch, C. Weber, S.-H. Lorentsen, F. Daunt and J.-Y. Georges helped analysing the data and compiling the maps. L. Drapeau provided digital depth charts. Four anonymous referees provided detailed comments and suggestions. We warmly thank all of them.

\section{LITERATURE CITED}

Adams NJ (1987) Foraging range of king penguins Aptenodytes patagonicus during the summer at Marion Island. J Zool Lond 212:475-482

Adams NJ, Navarro R (in press) Foraging of a coastal seabird: flight patterns and movements of breeding cape gannets (Morus capensis). Afr J Mar Sci

Adams NJ, Abrams RW, Siegfried WR, Nagy KA, Kaplan IR (1991) Energy expenditure and food consumption by breeding Cape Gannets Morus capensis. Mar Ecol Prog Ser 70:1-9

Ainley DG (1980) Seabirds as marine organisms: a review. Calif Co-op Ocean Fish Invest Rep 23:48-53

Ainley DG, Nur N, Woehler EJ (1995) Factors affecting the distribution and size of pygoscelid penguin colonies in the Antarctic. Auk 112:171-182

Ashmole NP (1963) The regulation of numbers of tropical oceanic birds. Ibis 103:458-473
Barta Z, Giraldeau LA (1998) The effect of dominance hierarchy on the use of alternative foraging tactics: a phenotype-limited producing-scrounging game. Behav Ecol Sociobiol 42:217-223

BBC (British Broadcasting Corporation) (2001) The blue planet. BBC Natural History Unit, Bristol

Berruti A (1987) Resident seabirds. In: Payne AIL, Crawford RJM (eds) Oceans of life off southern Africa. Vlaeberg, Cape Town, p 255-273

Berruti A, Colclough J (1987) Comparison of the abundance of pilchard in cape gannet diet and commercial catches off the western Cape, South Africa. S Afr J Mar Sci 5:863-869

Biro D, Guilford T, Dell'Omo G, Lipp HP (2002) How the viewing of familiar landscapes prior to release allows pigeons to home faster: evidence from GPS tracking. J Exp Biol 205:3833-3844

Birt-Friesen VL, Montevecchi WA, Cairns DK, Macko SA (1989) Activity-specific metabolic rates of free-living northern gannets and other seabirds. Ecology 70:357-367

Blanke B, Roy C, Penven P, Speich S, McWilliams J, Nelson G (2002) Linking wind and interannual upwelling variability in a regional model of the southern Benguela. Geophys Res Lett 29:1-4

Boinski S, Garber PA (2000) On the move, how and why animals travel in groups. Chicago University Press, Chicago

Brown CR, Brown MB, Ives AR (1992) Nest placement relative to food and its influence on the evolution of avian coloniality. Am Nat 139:205-217

Brown PC, Painting SJ, Cochrane KL (1991) Estimates of phytoplankton and bacterial biomass and production in the northern and southern Benguela ecosystems. S Afr J Mar Sci 11:537-564

Bürgi C, Werffeli S (1999) GPS System zur Aufzeichnung des Flugweges bei Brieftauben. MSc thesis, Institute for Electronics, Swiss Federal Institute of Technology, Zürich, p 1-69

Burger AL, Cooper J (1984) The effects of fisheries on seabirds in South Africa and Namibia. In: Nettleship DN, Sanger CA, Springer PF (eds) Marine birds: their feeding ecology and commercial fisheries relationships. Canadian Wildlife Service, Ottawa, p 150-160

Cairns DK (1989) The regulation of seabird colony size-a Hinterland model. Am Nat 134:141-146

Camphuysen K, Webb A (1999) Multi-species feeding associations in North Sea seabirds: jointly exploiting a patchy environment. Ardea 87:177-198

Coulson JC (2002) Colonial breeding in seabirds. In: Schreiber EA, Burger J (eds) Biology of marine birds. CRC Press, Boca Raton, FL, p 87-113

Crawford RJM, Shannon LV, Pollock DE (1987) The Benguela ecosystem. IV. The major fish and invertebrate resources. Oceanogr Mar Biol Annu Rev 25:353-505

Croll DA, Tershy BR, Hewitt RP, Demer DA and 8 others (1998) An integrated approach to the foraging ecology of marine birds and mammals. Deep-Sea Res II 45: 1353-1371

Danchin E, Wagner RH (1997) The evolution of coloniality: the emergence of new perspectives. TREE 12:342-347

Darling FF (1938) Bird flocks and the breeding cycle. Cambridge University Press, Cambridge

Davoken GK, Montevecchi WA (2003) Consequences of foraging trip duration on provisioning behaviour and fledging condition of common murres Uria aalge. J Avian Biol 34:44-53

Drapier M, Chauvin C, Thierry B (2002) Tonkean macaques (Macaca tonkeana) find food sources from cues conveyed by group-mates. Anim Cogn 5:159-165 
Forbes LS, Jajam M, Kaiser GW (2000) Habitat constraints and spatial bias in seabird colony distributions. Ecography 23:575-578

Furness RW, Birkhead TR (1984) Seabird colony distributions suggest competition for food during the breeding season. Nature 311:655-656

Garthe S, Benvenuti S, Montevecchi WA (2000) Pursuit plunging by northern gannets (Sula bassana) feeding on capelin (Mallotus villosus). Proc Roy Soc B 267: $1717-1722$

Grémillet D, Wilson RP, Gary Y, Storch S (1999) Threedimensional space utilization by a marine predator. Mar Ecol Prog Ser 183:263-273

Hamer KC, Phillips RA, Wanless S, Harris MP, Wood AG (2000) Foraging ranges, diets and feeding locations of gannets Morus bassanus in the North Sea: evidence from satellite telemetry. Mar Ecol Prog Ser 200:257-264

Hamer KC, Phillips RA, Hill JK, Wanless S, Wood AG (2001) Contrasting foraging strategies of gannets Morus bassanus at two North Atlantic colonies: foraging trip duration and foraging area fidelity. Mar Ecol Prog Ser 224: $283-290$

Hochscheid S, Grémillet D, Wanless S, du Plessis MA (2002) Black and white under the South African sun: are juvenile Cape gannets heat stressed? J Therm Biol 27:325-332

Hölldobler B (1976) Recruitment behavior, home range orientation and territoriality in harvester ants, Pogonomyrmex. Behav Ecol Sociobiol 1:3-44

Huin N (2002) Foraging distribution of the black-browed albatross, Thalassarche melanophris, breeding in the Falkland Islands. Aquat Conserv Mar Freshw Ecosyst 12:89-99

Hutchings L (1992) Fish harvesting in a variable, productive environment-searching for rules or searching for exceptions? In: Payne AIL, Brink KH, Mann KH, Hilborn R (eds) Benguela trophic functioning. S Afr J Mar Sci 12:297-318

Jackson S, Wilson RP (2002) The potential costs of flipperbands to penguins. Funct Ecol 16:141-148

King WB (1983) Seabird breeding habits. Oceanus 26:28-35

Lewis S, Sherratt TN, Hamer KC, Wanless S (2001) Evidence of intra-specific competition for food in a pelagic seabird. Nature 412:816-819

Lewis S, Benvenuti S, Dall'Antonia L, Griffiths R, Money L, Sherratt TN, Wanless S, Hamer KC (2002) Sex-specific foraging behaviour in a monomorphic seabird. Proc Roy Soc Lond B 269:1687-1693

Lutjeharms JRE, Monteiro PMS, Tyson PD, Obura D (2001) The oceans around southern Africa and regional effects of global change. South Afr J Mar Sci 97:119-130

McClain EP, Pichel WG, Walton CC (1985) Comparative performance of AVHRR-based multichannel sea surface temperatures. J Geophys Res 90:11587-11601

Naidoo AD, Verheye HM (eds) (2001) Research highlights 2000-2001, Vol 10. Marine and Coastal Management, Cape Town

Nelson JB (1978) The gannet. T \& AD Poyser, Berkhamstead

Nelson G (1992) Equatorward wind and atmospheric pressure spectra as metrics for primary productivity in the Benguela system. In: Payne AIL, Brink KH, Mann KH, Hilborn R (eds) Benguela trophic functioning. S Afr J Mar Sci 12: $19-28$

O'Reilly JE, Maritorena S, Siegel D, O'Brien MC and 18 others (2000) Ocean color chlorophyll a algorithms for SeaWiFS, OC2, and OC4: Version 4. In: Hooker SB, Firestone ER (eds) SeaWiFS postlaunch calibration and validation analyses. Part 3. SeaWiFS Postlaunch Technical Report Series 11. NASA, Goddard Space Flight Center, Greenbelt, MD, p 9-23
Orians GH, Pearson NE (1979) On the theory of central place foraging. In: Horn DJ, Mitchell RD, Stairs GR (eds) Analysis of ecological systems. Ohio State University Press, Columbus, p 154-177

Pitman RL, Ballance LT (1992) Parkinson petrel distribution and foraging ecology in the eastern pacific-aspects of an exclusive feeding relationship with dolphins. Condor 94:825-835

Portha S, Deneubourg JL, Detrain C (2002) Self-organised asymmetries in ant foraging: a functional response to food type and colony needs. Behav Ecol 13:776-781

Rand RW (1960) The biology of guano-producing birds. Chapter 3. The distribution, abundance and feeding habits of the cormorants Phalacrocoracidae off the southwestern coast of the Cape province. Investigational report 42. Division of Fisheries, Department of Commerce and Industries, Cape Town

Rolland C, Danchin E, de Fraipont M (1998) The evolution of coloniality in birds in relation to food, habitat, predation, and life-history traits: a comparative analysis. Am Nat 151: 514-529

Ropert-Coudert Y, Grémillet D, Ryan PG, Kato A, Naito Y, Le Maho Y (2004a) Between air and water: the gannet's plunge-dive. Ibis (in press)

Ropert-Coudert Y, Grémillet D, Ryan PG, Kato A, Naito Y, Le Maho Y (2004b) Behavioural adjustements to the constraints of central place foraging in cape gannets. Anim Behav (in press)

Schreiber EA, Burger J (2002) Biology of marine birds. CRC Press, Boca Raton, FL

Schoener TW (1979) Generality of the size-distance relation in models of optimal feeding. Am Nat 114:902-914

Serchuk FM, Kirkegaard E, Daan N (1996) Status and trends of the major roundfish, flatfish, and pelagic fish stocks in the North Sea: thirty-year overview. ICES J Mar Sci 53:1130-1145

Shannon LJ, Moloney CL, Jarre A, Field JG (2003) Trophic flows in the southern Benguela during the 1980s and 1990s. J Mar Sci 39:83-116

Shannon LV (1985) The Benguela ecosystem. Part I. Evolution of the Benguela, physical features and processes. Oceanogr Mar Biol Annu Rev 23:105-183

Steiner I, Bürgi C, Werffeli S, Dell'Omo G, Valenti P, Tröster G, Wolfer DP, Lipp HP (2000) A GPS logger and software for analysis of homing in pigeons and small mammals. Physiol Behav 71:589-596

Taylor SS, Leonard ML, Boness DJ (2001) Foraging trip duration increases for Humboldt penguins tagged with recording devices. J Avian Biol 32:369-372

von Hunerbein K, Hamann HJ, Ruter E, Wiltschko W (2000) A GPS-based system for recording the flight paths of birds. Naturwiss 87:278-279

Wanless S (1984) The growth and food of the young gannet Sula bassana on Ailsa Craig. Seabird 7:62-70

Wanless S, Harris MP (1993) Use of mutually exclusive foraging areas by adjacent colonies of blue-eyed shags (Phalacrocorax atriceps) at South Georgia. Colon Waterbirds 16: 176-182

Warham J (1996) The behaviour, population biology and physiology of the petrels. Academic Press, London

Weimerskirch H, Bartle JA, Jouventin P, Stahl JC (1988) Foraging ranges and partitioning of feeding zones in 3 species of Southern albatrosses. Condor 90:214-219

Weimerskirch H, Martin J, Clerquin Y, Alexandre P, Jiraskova $S$ (2001) Energy saving in flight formation - pelicans flying in a ' $\mathrm{V}$ ' can glide for extended periods using the other birds' air streams. Nature 413:697-698 
Weimerskirch $H$, Bonadonna $F$, Bailleul $F$, Mabille $G$, Dell'Omo G, Lipp HP (2002) GPS tracking of foraging albatrosses. Science 295:1259-1259

Wilson RP, Spairani HJ, Coria NR, Culik BM, Adelung D (1990) Packages for attachment to seabirds - what color do Adélie penguins dislike least? J Wildl Manag 54:447-451

Wilson RP, Pütz K, Peters G, Culik BM, Scolaro JA, Charrassin JB, Ropert-Coudert Y (1997) Long-term attachment of transmitting and recording devices to penguins and others seabirds. Wild Soc Bull 25:101-106

Wilson RP, Grémillet D, Syder J, Kierspel MAM and 7 others

Editorial responsibility: Otto Kinne (Editor),

Oldendorf/Luhe, Germany
(2002) Remote-sensing systems and seabirds: their use, abuse and potential for measuring marine environmental variables. Mar Ecol Prog Ser 228:241-261

Wood AG, Naef-Daenzer, B, Prince PA, Croxall JP (2000) Quantifying habitat use in satellite-tracked pelagic seabirds: application of kernel estimation to albatross locations. J Avian Biol 31:278-286

Yoda K, Naito Y, Sato K, Takahashi A, Nishikawa J, RopertCoudert Y, Kurita M, Le Maho Y (2001) A new technique for monitoring the behaviour of free-ranging Adélie penguins. J Exp Biol 204:685-690

Submitted: May 8, 2003; Accepted: December 4, 2003 Proofs received from author(s): March 2, 2004 